\title{
Selected Reference Books of 1980-81
}

T

1 HIS ARTICLE continues the semiannual series originally edited by Constance M. Winchell. Although it appears under a by-line, the list is a project of the Reference Department of the Columbia University Libraries, and notes are signed with the initials of the individual staff members. ${ }^{1}$

Since the purpose of the list is to present a selection of recent scholarly and general works of interest to reference workers in university libraries, it does not pretend to be either well balanced or comprehensive. A brief roundup of new editions of standard works, continuations, and supplements is presented at the end of the article. Code numbers (such as AE213, DB231) have been used to refer to titles in the Guide to Reference Books and its supplement. ${ }^{2}$

\section{BIBLIOGRAPHY}

European Americana: A Chronological Guide to Works Printed in Europe Relating to the Americas, 1493-1776. New York, Readex Books, 1980- . v.1- . (In progress) LC 80-51141. ISBN 0-918414-03-2.

At head of title: The John Carter Brown Library.

Contents: v.1, 1493-1600, ed. by John Alden. 467 p. $\$ 50$.

The chronological arrangement followed in this "guide" allows, for the first time in such a comprehensive bibliography, the sequential unfolding of events and their interpretations in the literature about America. Beginning with the announcements of Columbus' discovery and continuing through 1600 , this first volume covers a period when no printing presses were operating in America, so nearly every work published then which touched on

1. Paul Cohen, Rita Keckeissen, Anita Lowry, Eileen McIlvaine, Mary Ann Miller; Lehman Library: Laura Binkowski, Diane Goon.

2. Eugene P. Sheehy, Guide to Reference Books (9th ed.; Chicago: American Library Assn., 1976); Supplement (Chicago: American Library Assn., 1980). the American experience is cited. Ultimately, the coverage will reach the revolutionary war era and the work will consist of several volumes - the editors do not predict how many - which are already "well in hand" and scheduled for publication in the "near future."

When completed, European Americana should be the most important bibliography of Americana to have been produced in decades. Nonetheless, it will not completely supersede Sabin (Guide AA451), though it does overlap that work in some of its coverage. Sabin's dictionary arrangement has the drawback of making it impossible to effectively locate works within their historical framework. Thus, social historians and those interested in the "sense and flow of history" will be especially pleased with the perspective this new work offers; with the assistance of the computer, each entry has been recorded under the year of its appearance. Thousands of works unrecorded in Sabin are among the entries in this first volumeindeed, only one-quarter of them are in Sabin. Works in fields such as medicine, natural history, and literature, not recognized as "Americana" by Sabin, account for many of the new entries.

The bibliographical information in each citation reflects the completeness and accuracy one expects from John Alden. Locations of copies in more than 350 libraries and private collections in the United States and Europe are indicated, but full collations are not here- though the many citations to other bibliographies usually indicate where they can be found. There is an excellent index of topics, titles, and authors, and two useful lists of printers and booksellers, one alphabetical, the other geographical.-P.C.

\section{DICTIONARIES}

Chicago. University. Oriental Institute. The Hittite Dictionary of the Oriental Institute of the University of Chicago. Ed. by Hans 
G. Güterbock and Harry A. Hoffner. Chicago, The Institute, 1980- v. 3, fasc. $1-$. (In progress) LC 79-53554. ISBN 0-918986-27-3.

Contents: v.3, fasc. 1, L- -ma. \$9, pap.

"Designed for English speaking scholars and students" (Pref.), this dictionary of the earliest preserved Indo-European language is to be of intermediate length, giving "complete coverage of the representative occurrences of each Hittite word" without aiming to be exhaustive. It is based on lexical files that cover 90 percent of the published texts, and to a lesser extent on unpublished texts. Etymologies are not given as such, but an identifiable foreign source for borrowed words is indicated. Arrangement is much like that of the Institute's Assyrian Dictionary (Guide AD170), with entries divided into lexical, morphological, and semantic sections. Texts are indicated in the latter two sections; quotations and English translation and notes appear in the semantic paragraph. A provisional list of abbreviations is provided, and a complete list of Old and Middle Hittite corpora is planned. $-R . K$.

\section{Government Publications}

Rodgers, Frank. A Guide to British Government Publications. New York, Wilson, 1980. 750p. \$35. LC 80-322. ISBN 0-8242-0617-7.

Rodgers has expanded his 1971 Serial Publications in the British Parliamentary Papers, 1900-1968 (Guide AG80) into one of the most useful guides to the whole range of current British government publishing and publications. His presentation is organized by issuing body, grouping together each central department and its subagencies; this arrangement makes for clear order and, more importantly, is the arrangement that most libraries follow. A broad subject approach is still possible with this type of presentation if one looks under the names of the appropriate agencies. And there is a good index to the whole volume.

For the Parliament, each executive department, and all the subagencies of each Rodgers offers a discussion of the history and changes in function and describes the major publications, concentrating on "all annual administrative reports and important statisti- cal publications and serials."-Introd. For monographic titles the treatment is more selective, "the emphasis being on recent titles, particularly policy papers and those other documents that typify the predominant interests of the department." The discussion of each department ends with a short checklist of bibliographies of departmental publications and studies of the department or its agencies.

A tremendous amount of information is presented here, the discussion is clear, the selection of entries is judicious, and each entry is carefully annotated. Students and librarians will find the work a great help to an understanding of the organization and functions of the government as well as a good guide to the sources available. $-E . M$.

\section{BIOGRAPHY}

Biographical Books, 1950-1980: Vocation Index; Name/Subject Index; Author Index; Title Index; Biographical Books in Print Index. New York, Bowker, [1980]. 1557p. $\$ 75$. ISBN 0-8352-1315-3.

Just as we live in an age of computers, so do we live in an age of "spin-offs." This expensive compilation is derived from the database used to produce the American Book Publishing Record (Guide AA463) and its various cumulations. The so-called "Name/Subject Index" (the major portion of the book) reproduces the full cataloging information as found in $A B P R$ for all works in that database which are of a biographical nature-biographies, autobiographies, collective biographies, letters, diaries, journals, biographical dictionaries, and directories-published or distributed in the United States since 1950. Paperback and reprint editions are included, as is juvenile literature. Approach in the name/subject section is mainly by name of biographee, but form headings such as "Capitalists and financiers-U.S.," "Canada-BiographyDictionaries," and "Poets, American" are interfiled with the individual and family names. The vocation index provides a list of names in a given field; the author and title indexes refer to page numbers within the name/subject section. The "in print" index (which is a title listing giving publisher, price, and ISBN, but not the author's name) seems an unnecessary feature since the letters "BIP" 
follow the citations for in-print material in the name/subject section.

The preface states that the work "was produced from records stored on magnetic tape, edited by computer programs, and set in type by computer-controlled photocomposition,' leaving the impression that perhaps the machines were left to their own devices. Clearly some-or more-human editorial effort was in order. The preface boasts of 42,152 entries that were selected for inclusion, but there is a shocking number of duplicate entries for the same edition of a given work (e.g., three consecutive entries for a single edition of the letters of Sidney Lanier-who is entered both with and without birth/death dates, as is Frank Harris; Robert Frost gets in as "Frost, Robert" and as "Robert, Frost"). We are told that the database for an $A B P R$ Cumulative 1876-1949 supplies "the potential to publish information on biographies retrospectively to 1876 "; one can only hope that such an undertaking will receive the kind of careful editing we have come to expect in a Bowker publication. - E.S.

Notable American Women: The Modern Period. A Biographical Dictionary. Ed. by Barbara Sicherman [and others]. Cambridge, Belknap, 1980. 773p. \$35. LC 8018402. ISBN 0-674-62732-6.

Biographical sketches of 442 women who died between January 1, 1951, and December 31,1975 , constitute this supplement to the three-volume compilation Notable American Women (1971, Guide AJ46). Inasmuch as only five of the subjects of the basic set were born after 1900 , this volume brings "the story of women's achievements further into the twentieth century" (Pref.) through a judicious and representative selection of biographees. Four basic criteria for inclusion are noted: "the individual's influence on her time and field; the importance and significance of her achievement; the pioneering or innovative quality of her work; and the relevance of her career for the history of women." A special effort was made to include outstanding minority figures, and foreignborn women are included if they "had done important work in the United States and had significant influence here." The familiar pattern of signed contributions with appended bibliographies is observed, and there is a classified list of biographies.-E.S.

\section{PHILOSOPHY}

Handbook of World Philosophy: Contemporary Developments since 1945. Ed. by John R. Burr. Westport, Conn., Greenwood [1980]. 641p. \$45. LC 80-539. ISBN 0-313-22381-5.

The purpose of this survey of modern philosophy is to delineate "particular philosophic tendencies and cross-currents, . . . individual philosophers and the distinctive styles and content of their philosophizing."-Introd. Essays are intended "to provide an internationally representative sample since 1945 of the characters, directions, wealth, and varieties" of philosophic activities, "interpreted and evaluated by philosophers particularly knowledgeable about the region or country being discussed."

Arrangement is by region (Eastern Europe, Asia, the Americas, etc.), then alphabetic by country. Each chapter, written by an expert, identifies and describes the country's philosophers and their philosophies, concluding with a bibliography of books and articles. There are subject and name indexes, an international directory of philosophical associations, a list of congresses and meetings, and notes on contributors. This is a useful work for the college and university philosophy collection. - R.K.

The Philosopher's Index: A Retrospective Index to Non-U.S. English Language Publications from 1940. Ed. by Richard H. Lineback. Bowling Green, Ohio, Philosophy Documentation Center, Bowling Green State Univ., 1980. 3v. $\$ 180$. ISBN 0-912632-12-7.

Contents: v.1-2, Subject index; v.3, Author index.

This set is a companion to the publisher's Philosopher's Index: A Retrospective Index to U.S. Publications from 1940 (publ. 1978; Suppl. BA3), and similar to it in purpose, format, and arrangement. Included are about 5,000 English-language books issued from 1940 to 1978 , and about 12,000 Englishlanguage journal articles from some seventy periodicals published from 1940 to 1966; all appeared outside the United States. Periodical coverage thus antedates for twentyseven years the regular issues of the Philosopher's Index (Guide BA24), which begins in 1967. Books included are original and scholarly works in philosophy; translations, 
new editions, reference tools, textbooks, dissertations, etc., are excluded.

The subject index employs a list of descriptors, with books, parts of books, and journal articles entered by title in separate alphabets and giving author's full name. The author index provides full bibliographical details and, for most entries, brief abstract. With the publication of this work an important segment of philosophical scholarship can boast of excellent coverage for the past forty years. $-R . K$.

\section{LITERATURE}

Columbia Dictionary of Modern European Literature. $2 \mathrm{~d}$ ed., fully rev. and enl. Jean-Albert Bédé and William B. Edgerton, gen. eds. New York, Columbia Univ. Pr., 1980. 895p. \$50. LC 80-17082. ISBN 0-231-03717-1.

Some 500 scholars from the United States, Canada, and several European countries contributed to this thorough and very welcome revision of the 1947 edition of the Dictionary (Guide BD34). Not unexpectedly, it follows the pattern of the first edition, taking as its starting point "the period toward the end of the 19th century when Europe was swept by a wave of new literary movements" (Pref.), but writers were selected for inclusion "on the basis of their relevance to 20th-century literature." Entries for individual writers now total 1,853 , and surveys of the various national literatures are again a feature of the work. Articles-many of them newly prepared-are signed with the contributor's initials; revisions by different hands of articles from the first edition are so indicated. The brief bibliographies appended to the articles were compiled "especially with a view to meeting the needs of readers who may not be specialists in the literature to which the writer belongs." A work of this kind is a major editorial undertaking, but one hopes that another thirty-odd years need not elapse before the next revision. - E.S.

Greenfield, Stanley B., and Robinson, Fred C. A Bibliography of Publications on Old English Literature to the End of 1972. Toronto, Univ. of Toronto Pr., [1980]. 437p. $\$ 75$. LC 78-4989. ISBN 0-8020-2292-8.

Any urge to complain about the early cutoff date of this bibliography is largely dispelled by a reading of the preface with its history of the project and the deterrents to its completion. Building on a large and unstructured card file of publications to 1939 amassed by E. E. Ericson, Kemp Malone, and Stefán Einarsson, the compilers had not only to transcribe, verify, and classify citations on the existing cards, but to extend coverage through 1972. The resulting bibliography lists some 6,550 items (not counting the many citations to critical reviews). It intends to be exhaustive in its coverage of published writings on Old English literature: "studies of Anglo-Saxon social, political, and economic history, art history, archaeology, and linguistic questions" are omitted "except where such studies deal specifically with a literary aspect of a literary work in Old English."-Pref. The detailed table of contents, plus the author/ reviewer and subject indexes, makes for easy use of this scholarly compilation.-E.S.

Index of English Literary Manuscripts. Editorial board: P. J. Croft, Theodore Hofmann, and John Horden. London, Mansell; New York, Bowker, 1980-

v. 1- . (In progress) LC 79-88658. ISBN 0-8352-1217-3.

Contents: v.1 (in 2 pts.), 1450-1625, comp. by Peter Beal. $\$ 300$.

The ambitious aim of this Index is "to produce a catalogue of the surviving manuscripts of those works which are accepted as constituting English literature."-Introd. No such comprehensive census has ever been attempted before, and this first volume reveals the success of the pioneer undertaking. It took seven years to complete, and it reflects the holdings of hundreds of libraries and private collections throughout the world; included are bibliographies of some seventyfive writers who flourished between 1450 and 1625. Manuscripts from this early period are especially important as they were still used for the dissemination of texts even after the advent of printing. For each author a lengthy bibliographical essay precedes the entries for individual holographs, which include proof sheets, diaries and notebooks, marginal notes in printed works, and scribal copies. Bibliographical references and descriptions are provided as well as information on provenance and location. In addition to listing known manuscripts, the compilers have discovered numerous previously unrecorded ones in the course of their research. 
The series will eventually fill five volumes and will cover English literature up to the year 1900 . When completed, this important work with its numerous facsimiles will generously fill a gap long felt by scholars. It could also clarify some of our notions about literature: the "aggregation of valuable facts," the editors point out, "may lead to the clearer definition of some important themes in literary, historical, and sociological research."P.C.

\section{PERFORMING ARTS}

Armour, Robert A. Film: A Reference Guide. Westport, Conn., Greenwood, 1980. 215p. $\$ 29.95$. LC 79-6566. ISBN 0-313-22241-X. Of the general film book bibliographies that have been published, this is the first one composed of bibliographic essays, and therein lie its particular strengths. Since the essays are selective, descriptive, and evaluative, they direct the user to a number of the better, more substantial monographic sources on film (though, as with any selective listing, one could question the inclusion or exclusion of individual titles). The bibliography is limited to books written in English, including translations, and relevant to the study of American popular film. Each chapter covers a broad subject area (e.g., film production, or film and related arts), which is further divided by appropriate topics; these topics correspond well to many of the most important aspects of American film history and popular approaches to film study. The bibliographic essays themselves provide an intelligent, if general, introduction to the serious consideration of film and writing about film. There is a subject index and an index of authors, editors, and interviewees. All of these things make this guide a good and easy-to-use source for students writing research papers or for general readers interested in a variety of film topics. In addition, there is a chapter on "Reference Works and Periodicals" (the periodicals list is particularly good) and an appendix on "Research Collections," features that would be useful in libraries not having more specialized guides to film research. $-A . L$.

Bronner, Edwin. The Encyclopedia of the American Theatre, 1900-1975. San Diego and New York, Barnes; London, Tantivy
Press, [1980]. 659p. il. \$30. LC 75-2439.

ISBN 0-498-01219-0.

"Encyclopedia" seems not quite the appropriate term for this very informative work: apart from an omnibus entry for the Federal Theater Project, it is basically a dictionary arrangement of entries for individual plays "written (or adapted) by American or AngloAmerican authors" (Introd.) and produced on Broadway or off-Broadway during the 1900 75 period. Entries include date of opening of the play, theater, number of performances in the original run, a brief synopsis of the play (usually including references to the stars, critical judgment of the compiler, and, often, brief quotations from contemporary reviews), principal players, author, producer, director, and notes on revivals. Musicals are not included, although references to musical versions of the plays are mentioned in the notes; screen versions are also noted, but no crossreferences or index entry is provided when the title of the musical or screen version differs from the original. Six appendixes help to justify the "encyclopedia" designation: (1) a calendar of notable premieres (including musicals and foreign plays); (2,3) Broadway debuts of actors and playwrights; (4) the 100 longest-running Broadway productions, 1900-75; (5) statistical record of Broadway productions by season; (6) awards. The index is of personal names only, but includes all names mentioned in the entries and in the appendixes.-E.S.

Rowan, Bonnie G. Scholars' Guide to Washington, D.C. Film and Video Collections.

Washington, Smithsonian Institution Pr., 1980. 282p. (Scholars' Guide to Washington, D.C., 6) \$25. LC 80-607014. ISBN 0-87474-818-6.

Published for the Woodrow Wilson International Center for Scholars.

The social scientist studying "mass media," the film scholar analyzing "cinema," the historian examining "visual documentation"these scholars and students are often frustrated in their research by the difficulty of finding locations for films and video materials. There have been few directories or union catalogs for film and video archives, none of them covering the rich resources, both public and private, of the Washington, D.C., area. So this guide fills a definite need and fills it 
very well by providing detailed information on the "collections, referral services, and academic programs" that make film and video available for scholarly research or provide information about such collections. The resources range from major repositories like the National Archives and Records Service (whose collections are described in forty-two pages, with index) and the Library of Congress (ten pages) to smaller but important collections in colleges and universities, public libraries, embassies, and other private organizations. Each entry includes a description of collections (giving examples rather than a complete listing of titles held), information about catalogs, instructions concerning access and eligibility, and a brief description of related collections of interest.

The ten appendixes are practically a book in themselves: "Television Stations, Services, Broadcasts"; "Public School System Media Collections"; "Other Film and Video Collections in the U.S."; "Theaters/Film Series"; "Media Organizations and Publications"; "Films in a Washington Setting"; "Note on Government Paper Records/Bibliographic Guide for Films and Video Studies"; "Technical Services/Commercial Distributors"; "Transportation/Housing/Services"; "Federal Government Holidays." Finally, there are five separate indexes, making an already valuable book even more-valuable and easy to use. - A.L.

\section{MUSIC}

The New Grove Dictionary of Music and Musicians. Ed. by Stanley Sadie. [London, Macmillan, 1980] 20v. il. \$1,900. LC 7926207. ISBN 0-333-23111-2.

It is somewhat presumptuous to deal with a work of this magnitude in a note restricted to a few hundred words. At best one can hail its long-awaited appearance and mention a few salient features. Although firmly based on A Dictionary of Music and Musicians by Sir George Grove (1st ed. 1878; 5th ed. and suppls. 1954-75; Guide $\mathrm{BH} 78$ ), this is virtually a new work retaining only about 3 percent of the material from earlier editions. It no longer emphasizes the nineteenth century, but the dictionary does reflect "the tastes and preferences of the Englishspeaking countries" (Pref.) while it "seeks to discuss everything that can be reckoned to bear on music in history and on present-day musical life."

More than half the entries are for composers, but performers, scholars, theorists, patrons and publishers of music, and people in other arts whose work was important to music find their place here. Terminology and musical genres and forms are fully treated; institutions, orchestras, and societies are given their due; and there are entries for cities and towns with significant musical traditions. Most articles are signed (the approximately 2,500 contributors are listed in volume 20); longer articles generally follow a uniform structure; and bibliographies include both studies used as source materials and recommended readings. Lists of compositions are an important feature and "are designed not only to show a composer's output .... , but also to serve as a starting-point for its study."-Introd. British terminological usage may present an occasional difficulty for the American user; on the other hand, volume 20 includes a helpful "Index of terms used in articles on non-Western music, folk music and kindred topics."-E.S.

\section{SOCIOLOGY}

Ballou, Patricia A. Women: A Bibliography of Bibliographies. Boston, G. K. Hall, 1980. 155p. \$16. LC 80-21042. ISBN 0-91618292-2.

The outgrowth of a survey article originally published in the periodical Signs (1977), this carefully selected list of more than 500 bibliographies will be welcomed by students and librarians as an excellent starting point for women's studies research. Included are works published from 1970 through 1979 that are "concerned primarily with women or with a topic traditionally associated with women."-Introd. Listed are both "annotated and unannotated lists of citations, bibliographic essays, literature reviews, library catalogs and guides to archives or manuscript repositories" published as books, parts of books, pamphlets, journal articles, or in microform.

A classified arrangement is used, with first a general section, then geographical subjects (i.e., works concerning women in an individual country or state), then topical subjects such as history, literature, sociology, etc., 
with subdivisions as needed. Helpful annotations, chiefly descriptive in character, note number of entries, arrangement, scope, and special features. The detailed table of contents serves for a subject search; there is a name index.-R.K.

\section{Harvard Encyclopedia of American Ethnic} Groups. Ed. by Stephan Thernstrom [and others]. Cambridge, Harvard Univ. Pr., 1980. 1,076 p. $\$ 60$. LC $80-17756$. ISBN 0-674-37512-2.

Whether one subscribes to the "melting pot" theory of ethnicity or one prefers the "salad bowl" explanation, the appearance of this encyclopedia is cause for general rejoicing. From Acadians to Zoroastrians, 106 different ethnic groups and their social, cultural, religious, linguistic, political, and economic past and present are represented in articles written by scholars. Each article is accompanied by a critical bibliography and usually a map of the homeland. Great care has been taken to include not only the foreign-born groups but also the native populations such as the Indians and the Eskimos, the distinctive regional clusters (e.g., Southerners and Yankees), as well as the other "made in America" groups such as the Amish and the Mormons.

Twenty-nine substantial thematic essays, also contributed by highly qualified specialists, address the broader issues of ethnicity: topics such as pluralism, assimilation, language maintenance, immigration, intermarriage; and, of particular note for librarians and investigators, there is an entry for resources and research centers. These articles are interfiled in the same alphabet as the ethnic entries, and one regrets the dearth of cross-references and the absence of a comprehensive index.

The major impact of this source book is twofold. One is delighted to discover entries on groups that heretofore have received very little treatment. Conversely, for those groups that benefit from extensive coverage in the literature of ethnicity, this encyclopedia provides an excellent introductory focus to the overwhelming output. It is a remarkable product of academic scholarship stimulated by the ethnic consciousness of the late sixties and early seventies and reflecting the rich diversity and pervasive influence of our collective heritage. - L. B.
International Handbook on Aging: Contemporary Developments and Research. Ed. by Erdman Palmore. Westport, Conn., Greenwood, [1980]. 529p. \$35. LC 7874802. ISBN 0-313-20890-5.

Scholars in twenty-eight countries were requested by the International Association of Gerontology to submit evaluative essays on gerontological work in their respective countries for this state-of-the-art compilation. Each essay discusses the roles and status of the aged in a given country, the history of gerontology research (including research in progress), programs for the aged, and sources of further information. A bibliography of major works ends each essay; it often includes publications as recent as 1979 . The articles are informative and readable, and are enhanced by tables summarizing the statistical data. Two appendixes give names and addresses of major organizations concerned with gerontology problems and research. The volume ends with a very workable index.

Most of the countries surveyed have a large number of people over age sixty-five (usually more than 7 percent of the population) and are highly urbanized. But there are exceptions, e.g., Venezuela with a low proportion of aged, and Yugoslavia not highly urbanized (yet those two countries have programs of research on aging). Two countries omitted because of time restrictions are Sweden and Australia; they are to be included in later editions. - E.M.

\section{GEOGRAPHY}

Rand McNally Encyclopedia of World Rivers. Chicago, Rand McNally, [1980]. 350p. il. $\$ 24.95$. LC 79-87898. ISBN 0-528-81048-1.

First published in the United Kingdom (London, Bison Books, 1980).

It seems a shame that this very handsome and informative volume was not fitted with the index and bibliographic apparatus that would have made it such a much more valuable reference tool. As it stands, we have a listing by continent of hundreds of rivers, large and small, with varying amounts of information about each, and a multitude of striking illustrations. "The major considerations in selecting the rivers were length, natural beauty and geographic importance. However, a myriad of smaller rivers were also 
included because their banks provided sites for important towns, they were once significant trade routes or they were the scenes where historic events-battles, conferences and the like-occurred."-Introd. Inset maps locate the major rivers, and those rivers are also treated in some depth. A special effort was made to reconcile conflicting statistics on the length of individual rivers. $-E . S$.

\section{HISTORY}

Mitterling, Philip I. L'.S. Cultural History. Detroit, Gale, 1980. 581p. (American Government and History Information Guide Series, V.5) \$28. LC 79-24061. ISBN 0-8103-1369-3.

This is another in the line of subject bibliographies published by Gale that is especially well suited to the general reader, the college student, and their librarians. The author has chosen to emphasize intellectual history because social history, though once under the umbrella of cultural history, "is now attempting to achieve an identity with distinctive content. "-Pref. To describe the bibliography's scope would be to say, perhaps, that it covers almost any aspect of American life that has been studied for its influence on American thought. Subjects range from Eli Whitney to Robert Frost, from flappers to farmers, and to the role of intellectuals in the designing of the industrial state.

The seven chapter headings reflect the obvious subjects of cultural history: "Architecture and the Arts," "Biography," "Historiography," "Popular Culture," etc. Each chapter is divided into three periods: Colonial to 1815,1815 to 1915 , and 1915 to the present. All entries are annotated, often critically, and they are indexed by author, title, and subject. The subject index, being derived from the annotations, offers thorough, analytical access to the material. The indexing, the annotations, and the chapter on reference materials especially recommend this book to the general reader. It is a well-conceived and well-wrought guide to sources that until now have been widely scattered.-M.A.M.

Smith, Myron J. The Secret Wars: A Guide to Sources in English. Santa Barbara, Calif., ABC-Clio, [1980]. 3v. (War/Peace Bibliography Series, no.12-14) LC 79-25784.
Contents: v.1, Intelligence, propaganda and psychological warfare, resistance movements, and secret operations, 19391945 (260p. \$34.50. ISBN 0-87436-271-7); v.2, Intelligence, propaganda and psychological warfare, covert operations, 1945-1980 (320p. \$42.50. ISBN 0-87436-303-9); v.3, International terrorism, 1968-1980 $(237 \mathrm{p}$. \$33.75. ISBN 0-87436-304-7).

This work represents the latest volumes in a series developed in cooperation with the Center for the Study of Armament and Disarmament at California State University, Los Angeles; each issue in the series "is intended to provide a comprehensive working, rather than definitive, bibliography on a relatively narrow theme within the spectrum of war/ peace studies," $-r .1, p$. [rii].

The Secret Wars is thus more accurately described as a bibliography rather than a guide, since introductory sections are brief and do not evaluate the literature; brief annotations are provided only to clarify title content. The selection criteria emphasize published sources-books, periodical articles, government documents, doctoral dissertations, master's theses, and scholarly papers produced through mid-1979: each of the three volumes contains more than 2,500 entries. Detailed tables of contents serve as a sort of classified subject index, with author and subject indexes provided for the first two volumes, and an author index for the third. Selected chronologies and lists of relevant journals are also included.

Smith has compiled at least eighteen other bibliographies in the field of military studies, and he gives generous notice to related, annotated bibliographies such as Blackstock and Schaf's volume on intelligence and covert operations (Suppl. CJ6) and Mickolus compilation on terrorism (Suppl. CJ17). Clearly, however, this impressive addition to an impressive series should be in every research library with collections in history, political science, international relations, or international law. -D.G.

\section{SCIENCE \& TECHNOLOGY}

A Guide to the Culture of Science, Technology, and Medicine. Paul T. Durbin, gen. ed. New York, Free Pr., 1980. 723p. \$45. LC 79-7582. ISBN 0-02-907820-2. 
The editors of this compilation of essays and bibliographies are concerned that researchers and teachers are not addressing the "value" or ethical questions raised by science, technology, and biomedicine, a problem they see in the "two cultures" of C. P. Snow and in the fragmentation of the "humanistic and social science disciplines focusing on science and technology."-Introd. As a partial remedy, they commissioned specialists to produce surveys of various aspects of the history, philosophy, and sociology of science, technology, and medicine (e.g., "Medical Sociology and Science and Technology in Medicine" and "Science Policy Studies"). Each contributor was expected to focus "explicitly on the help the discipline might afford to those attempting to deal with major contemporary value questions" and whenever possible to refer to other fields.

A description of one of the nine sections will serve to make the purpose and content clearer. The essay "Philosophy of Science" offers a brief survey of the history of the subject from Plato to Ernst Mach, followed by a country-by-country account of twentiethcentury studies outside the Anglo-American school. It then considers Anglo-American approaches to the philosophy of science and ends with a short exposition of the social responsibility of scientists. The appended bibliography offers a short list of the "classics" in the field, followed by twenty-seven pages of citations to relevant books, articles, and essays.

Bibliographies accompanying the other essays are equally extensive, with the "classics" section often offering much more guidance (e.g., citing dictionaries and encyclopedias, major journals, "staple reference works," museums and archives). Essays do not touch on certain topics, such as science and literature; antiscience and antitechnology; science and technology; and law, science, and religion; or they treat them only incidentally, as in the case of environmental issues. However, this is a well-written and carefully researched compilation that is sure to become a major reference guide.-E.M.

Pritchard, Alan. Alchemy: A Bibliography of English-Language Writings. London, Routledge \& Paul, 1980. 439p. \$75. LC 80-40147. ISBN 0-7100-0472-9.
To appreciate how widely the literature of alchemy is dispersed throughout the fields of the humanities and the sciences and to be fascinated by its many facets, one need only peruse this bibliography's entries and its "list of major sources searched." There are, for example, references to Chinese folklore, Taoism, the history of Hindu chemistry, Jungian psychology, Shakespeare's sonnets, and yoga-evidence of Pritchard's determination to chart for the first time both the main arteries and the many byways the art of alchemy has traveled. He attempts comprehensive coverage of all types of Englishlanguage writings about alchemy: the texts first, then the books, dissertations, articles, and pamphlets, arranged by country, or by subject if an item is general in nature. It is in ferreting out the secondary sources that Pritchard has pioneered: he has searched, page-by-page if need be, the general literature as well as the privately printed and esoteric publications from earliest times to 1975.

Because the chief concern was to be eclectic, no attempt was made to provide a complete record of every edition, nor full citations. Annotations are few and terse, but when a work not directly concerned with alchemy is cited there are notes to indicate its relevance, and there is a good subject index. The bibliography is a reflection of the compiler's ideas about alchemy (to which he gives expression in the introductory material) and the work as a whole will serve a wide range of users, from those wanting a definition of alchemy to those deeply involved in its study.-M.A.M.

\section{NEW EdITIONS, SUPPLEMENTS, ETC}

Approximately 6,000 serials reprinted by some 260 publishers are listed in Band 2 of the Internationale Bibliographie der Reprints (München, K. G. Saur, 1980. 566p. \$89.50; Bd.1 publ. 1976, Suppl. AA94). Designated as "Periodicals, Newspapers, Annuals, Conference Reports, etc.," this volume includes many irregular publications and statistical reports in addition to the categories named. Keyword and classified indexes are included.

Nearly three times as many items-books, parts of books, and periodical articles-are cited in the second, revised and enlarged edi- 
tion of Alan R. Eager's Guide to Irish Bibliographical Material (Westport, Conn., Greenwood, 1980. 502p. \$65) as appeared in the 1964 version (Guide AA53). The new work follows the same classified arrangement (based roughly on Dewey), with author and subject indexes.

The Second Barnhart Dictionary of New English (Bronxville, N.Y., Barnhart/Harper, 1980. 520p. \$19.95) is a continuation of the 1973 Barnhart Dictionary of New English (Guide AD68), the two volumes now including some 10,000 "words and meanings not entered or inadequately explained in standard dictionaries."-Pref. The new volume provides a date for the compilers' earliest evidence for use of a new word or meaning.

"No longer will all of the sketches in a given Contemporary Authors volume [Guide AJ33] be updated and published together as a revision volume. Instead, sketches from a number of volumes will be assessed, and only those sketches requiring significant change will be revised and published in a Contemporary Authors New Revision Series volume." Thus the preface to the first volume of the New Revision Series (Detroit, Gale, 1980. 736p. \$62) explains the policy for preparation of revised volumes. Updated sketches from previous revisions will also be included, and the latest Contemporary Authors cumulative index will continue to index the revised volumes.

Designated as the fifth edition, the new Répertoire International des Médiévistes (Paris, etc., K. G. Saur, 1979. 2v. \$129) issued by the Institut de Recherche et d'Histoire des Textes is a continuation of the Labande and Leplant work of the same title (1971; Guide AJ36). It offers biobibliographies of some 6,000 medievalists in forty-three countries and lists their publications that have appeared since 1969. Geographical and specialty indexes are not provided in this edition.

The Philosopher's Guide to Sources, Research Tools, Professional Life, and Related Fields by Richard T. DeGeorge (Lawrence, Regents Pr. of Kansas, 1980. 261p. \$20) represents a thorough reworking, updating, and expansion of the compiler's Guide to Philosophical Bibliography and Research (1971; Guide BA2). There are now three main sections: (1) philosophy; (2) general research tools; (3) related fields; each is appropriately subdivided. The index includes authors, subjects, and most titles.

Studies of short fiction published 1976-78 are cited in Supplement I to the Third Edition (Hamden, Conn., Shoe String, 1980. 257p. $\$ 27.50)$ of Warren S. Walker's TwentiethCentury Short Story Explication (1977; Suppl. BD31). Some 186 additional authors are treated, along with new citations to authors dealt with in the basic volume. Citations to earlier publications previously overlooked have also been included.

Virginia Brokaw Gerhardstein is the compiler of the fourth edition of Dickinson's American Historical Fiction (Metuchen, N.J., Scarecrow, 1981. 312p. \$15; 3d ed. 1971; Guide BD318). This edition lists 2,755 novels, with brief annotations "designed to place the books in historical perspective rather than to make any critical judgment of the quality or the historical accuracy of the writing."-Pref.

The Avery Obituary Index of Architects (Boston, G. K. Hall, 1980. 530p. \$75) represents a new edition of the Avery Obituary Index of Architects and Artists (1963), the change of title stemming from the fact that obituaries of artists have not been indexed since 1960. Begun in 1934, the index cites obituary notices appearing in the approximately 500 periodicals currently indexed in the Avery Index to Architectural Periodicals (Guide BE58) and in some newspapers (mainly the New York Times). In addition, there is back-indexing of obituaries in four leading American architectural periodicals to the dates of their founding, and some retrospective indexing of selected English, French, and German periodicals.

Because it is intended both as companion and continuation of the 1974 compilation (Suppl. BG7), the new volume of Gordon Samples' Drama Scholars' Index to Plays and Filmscripts (Metuchen, N.J., Scarecrow, 1980. 695p. \$30) has been designated "Volume 2 " rather than a supplement. "Indexing for the second volume goes back to the beginning of recorded literature and continues through 1977."-Introd. Plan and principles of the work remain the same; a title list of anthologies indexed in both volumes 1 and 2 is included.

Biographical sketches of some 8,200 individual members (both living and deceased) of 
the American Society of Composers, Authors and Publishers are included in the fourth edition of the ASCAP Biographical Dictionary (New York, Jaques Cattell Pr./Bowker, 1980. 589p. \$43.95). This represents an increase of approximately 3,000 entries over the third edition (1966; Guide BH63).

Descriptions of public records, business records, and "artificial collections" (including manuscript volumes and documents acquired singly) make up the second volume of the Guide to the Manuscripts in the National Maritime Museum (London, Mansell, 1980. 216p. \$40; v.1 publ. 1977, Suppl. CJ171). The two volumes constitute a statement of the Greenwich museum's holdings at the end of the 1970 s, and a general index to both volumes is provided in volume 2.

Kraus Reprint has issued a "revised and corrected edition" of Louis John Paetow's Guide to the Study of Medieval History (Millwood, N.Y., Kraus, 1980. cxiii, 643p. $\$ 50)$ "with errata compiled by Gray C. Boyce and an addendum by Lynn Thorndike." The work is a reprinting of the 1931 edition (Guide DA108) with the addition of the errata section (p.xxi-li) and an addendum (p.liii-cxii) of titles of books and articles not cited in previous editions. Items in the latter section are keyed to appropriate sections of the main work. Only works published through 1930 are included since Boyce's supplement covering $1930-75$ has just appeared and will be noticed in this column at a later date.

Michael C. Meyer's Supplement to A Bibliography of United States-Latin American Relations Since 1810 (Lincoln, Univ. of Nebraska Pr., 1979. 193p. \$19.50) is companion to the Trask, Meyer, and Trask volume of similar title published 1968 (Guide DB27). The supplement follows the plan of the earlier work and provides cross-references thereto. Of the 3,568 entries, about three-quarters are post- 1965 publications, the others being older materials not included in the basic volume. - E.S. 


\section{New scholarly and professional titles in life sciences from Dr. W. Junk Publishers

\author{
Boston/The Hague A Kluwer Company
}

\section{THONNER'S ANALYTICAL KEY TO THE FAMILIES OF FLOWERING PLANTS}

edited by R. Geesink, A.J.M. Leeuwenberg, C.E. Risdale, and J.F. Veldkamp, State Herbarium. the Netherlands

Leiden Botanical Series, vol. 5

This classic key is now available in English and includes updates from four botanists. It covers plant families of the whole world with emphasis on the tropics. The system adopted is mainly that of Engler (as modified by Melchior, 1964, Engler's Syllabus) but many of the "split families" are accepted. As far as possible both "split family" and "lumped family" are keyed out separately.

ISBN 90-6021-461-7

Available

$200 \mathrm{pp}$.

\section{THE RADIATION REGIME AND}

\section{ACHITECTURE OF PLANT STANDS}

by Juhan Ross, Astrophysical and Astronomical Institute, USSR

Tasks for Vegetation Science 3

This monograph is the first of its kind in world literature to ofer a systematic presentation of a scientific branch, which borders on geophysics, on one hand, and biology, on the other, and deals with solar radiation transfer in plant stand. The author, J. Ross, is the founder of the Tartu school of actinometry, which has gained recognition both within and outside the

U.S.S.R. in view of the fact that the radiation regime of plant stand is closely related to its architecture, the author found it necessary to accurately formulate methods of strict quantitative study of the structure of an individual plant as well as a plant stand as a whole. The monograph gives a quantitative theory of the plant stand radiation regime, that is based essentially on the vast body of experimental material obtained by the author, as well as by other workers.

ISBN 90-6193-607-1

July

$480 \mathrm{pp}$.

$\$ 115.00$

\section{THE ECOLOGY OF BRUCHIDS ATTACKING LEGUMES Proceedings of the International Symposium held at Tours, 1980 edited by V. Labeyrie \\ Series Entomologica 19}

The F.A.O. and the International Organization for Biological Control sponsored this study of bruchids of pulses, and the necessary knowledge of crop infestation in order to achieve efficient protection. There are bruchid species which have been able to colonize habitats, some differing in their latitude and thus basic periodicity, while others differ in their degree of complexity (i.e. stock of seeds). The qualitative and quantitative evolution of bruchid populations, and their coevolution with legumes were examined by a group of biochemists, physiologists, and ethologists.

The methodology adopted to solve the human problems generated by bruchid-caused destruction will provide a model for an ecological approach to crop protection. The conference resulted in the creation of a working group attached to the I.O.B.C. which includes botanists, ethnologists, and entomologists.

ISBN 90-6193-883-X

Available

$240 \mathrm{pp}$.

$\$ 63.00$
THE LARGE WHITE BUTTERFLY edited by John Feltwell

Series Entomologica 18

This book is a source for relevant literature and an introduction to all aspects of the white butterfly. The aim of the author has been to assemble as many references as possible, to abstract facts, figures, ideas and methods, and fit them into a text which treats the biology of $P$. brassicae in a logical manner. The $4000+$ references include key papers on the insect, over 50 theses and diplomas as well as notes and personal communications. The book provides up to date work and illustrates the recent advances made in biochemical and chemosensory systems. Much physiological information has been drawn from papers by biochemists dealing with the effects of insecticides.

ISBN 90-6193-128-2

August

$560 \mathrm{pp}$.

$\$ 98.00$

\section{SUPERFICIAL KERATITIS}

edited by P.C. Maudgal and L. Missotten, Catholic University of Leuven, Belgium Monographs in Ophthalmology, 1

This report concentrates on the diseases of the superficial corneal layer which forms the most important surface in the optical system of the eye. It discusses at length the common disorders of the epithelium, and other relevant conditions important in the differential diagnosis and treatment of superficial keratitis. Included in this discussion of each disorder are: etiology, epidemiology, clinical picture, histopathology, pathogenesis, and treatment.

ISBN 90-6193-801-5

Available viii+192 pp.

$\$ 45.00$

PHARMACOLOGICAL DENERVATION AND GLAUCOMA

\section{A Clinical Trial Report with Guinethidine and Adrenaline}

Philip F.J: Hoyng, The Netherlands Ophthalmic Research Institute

Monographs in Ophthalmology, 2

The availability of a new eyedrop combining adrenaline and gaunethidine has prompted this study of an alternative treatment of glaucoma. The purpose of this study was to investigate the effect of these eyedrops in patients with open angle glaucoma and glaucoma suspects. The study extended over a period of four years $(1976-1979)$ and involved 68 patients.

ISBN 90-6193-802-3

Available ix+150 pp.

$\$ 34.50$

Please use ISBN when ordering these Dr. W. lunk books - from your bookseller, or direct from our North American distribution center.

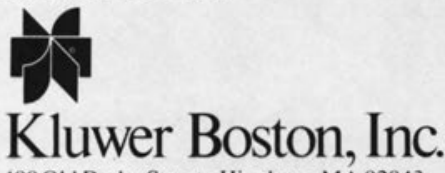

190 Old Derby Street $\cdot$ Hingham, MA 02043

617-749-5262 


\section{announcing important new additions}

to the scientific literature...

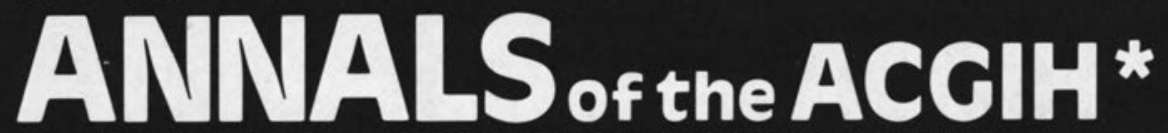

^The American Conference of Governmental Industrial Hygienists

\section{about ACGIH...}

Organized in 1938, ACGIH members are professional personnel in governmental agencies or educational institutions engaged in occupational health and safety programs. The work of its committees and its publications are recognized and respected worldwide, as are ACGIH expertise and contributions to the improvement of occupational safety and health standards.

\section{about the ANNALS...}

An important aspect of ACGIH activities is the sponsoring of an ongoing series of topical symposia on subjects of current importance to occupational safety and health professionals. Reflecting the latest state-of-the-art information, the papers presented at these symposia, and others of comparable merit, will be published periodically as a series of ANNALS of the ACGIH.

\section{soon to be released...}

Volume 1 - DOSIMETRY FOR CHEMICAL AND PHYSICAL AGENTS -overview of chemical and physical aspects/monitoring and reporting to meet regulatory requirements/passive monitors/physical agents/instrumentation ACGIH topical symposium, October 6-8, 1980. Available Fall ' 81.

Volume 2 - AGRICULTURAL RESPIRATORY HAZARDS - cotton/ agents, metabolites, environments/infectious and immunologic agents, dusts/grain dusts ACGIH topical symposium, January 13-15, 1981. Available early ' 82 .

Volume 3 - TRANSACTIONS OF THE 43RD ANNUAL MEETING -history/officers/committees/awards/ lectures/business meeting/committee reports/new TLV's ACGIH annual meeting, May 24-29, 1981. Available early ' 82.

Volume 4 - HEALTH SERVICES FOR SMALL PLANTS - health protection litigation/key issues/provision of health services/noise, chemical hazards, injuries, alcoholism, drug abuse, mental health ACGIH topical symposium, October 26-28, 1981. Available Fall ' 82.

Volume 5-PROTECTION OF THE SENSITIVE WORKER - defining, recognizing the sensitive individual/ occupational exposure limits/employer-employee relations/legal \& ethical issues ACGIH topical symposium, November 9-11, 1981. Available Fall '82.

Page counts and prices to be announced. Library-quality books, hard covers.

\section{START YOUR ANNALS}

of the ACAII

COLHJCTION NOWII!

WRITE TODAY FOR ORDERING INFORMATION

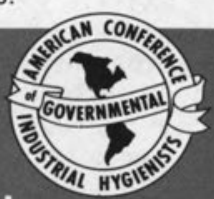

library discounts offered/subscription agency inquiries invited.

\section{PUBLICATIONS SECTION, ACGIH}

Send me all the facts on the new ANNALS of the ACGIH series.

6500 Glenway Ave.

Bidg., D-5, Dept. K.

Cincinnati, $\mathrm{OH} 45211$

(513) 661-7881

name

affiliation

street address

city

state

zip 